\title{
Felhívás
}

\section{Call for thematic issue}

A Tér és Társadalom szerkesztősége lehetőséget kínál egy 2018-ban (4. számként) megjelenő tematikus szám megpályázására. A pályázaton olyan szerzői kollektívák vagy intézményi kutatócsoportok vehetnek részt, akik

- a Tér és Társadalom profiljához illő témát kínálnak,

- a felkínált téma a hazai regionális tudomány számára új elméleti vagy empirikus eredményekkel szolgál,

- a tanulmányok máshol még nem jelentek meg, de lehetőleg már végéhez közeledő vagy lezárt kutatás eredményeiről számolnak be,

- a szerzők betartják a TéT tudományos, etikai és formai követelményeit,

- a pályázat beadója egyben vállalja a vendégszerkesztői megbízatást.

A pályázat tartalmazza a téma kb. 2 oldalas szinopszisát, a tervezett cikkek szerzőinek és az írások címeinek felsorolását, valamint azok rövid tartalmának bemutatását 1-1 bekezdésben. A tematikus lapszámok kb. 7-10 tanulmányból állnak, de a lektorálás során tapasztalt elutasítási arányok alapján kérjük, hogy a pályázatok legalább 10 tanulmányt javasoljanak a tematikus lapszámba. Az ideális pályázat megtölti a folyóirat egyéb rovatait, azaz recenziókat és a Tudományos élet rovatba szánt írásokat is ajánl.

A TéT szerkesztősége választja ki a pályázat győztesét, amelyben a döntő kritérium a pályázat szakmai tartalmának minősége. Mivel kb. évi 4 millió $\mathrm{Ft}-\mathrm{ba}$ kerül a lap fenntartása, így a lapszám megjelenését részben vagy egészében finanszírozni képes pályázatokat azonos szakmai színvonal esetén előnyben részesítjük.

A kéziratok leadásának várható időpontja: 2018. június 30. A szerkesztőség vállalja, hogy elvégzi a szükséges szerkesztői munkálatokat (a vendégszerkesztővel együtt részt vesz a lektorálás megszervezésében, a lektorálási folyamat lebonyolításában, valamint a nyomdai előkészítés, a nyomdai munkálatok és a terjesztés szervezésében).

A pályázatokat a tet@rkk.hu címre várjuk elektronikus formában.

A pályázat beadási határideje: 2018. január 31.

Eredményhirdetés: 2018. február 28.

A Tér és Társadalom szerkesztősége 